\title{
Differential p53 phosphorylation and activation of apoptosis-promoting genes Bax and Fas/APO-1 by irradiation and ara-C treatment
}

Tohru Kobayashi ${ }^{1,5}$, Sanbao Ruan ${ }^{1}$, James R. Jabbur ${ }^{1}$, Ugo Consoli ${ }^{2}$, Katharina Clodi ${ }^{2}$, Hiroshi Shiku, Laurie B. Owen-Schaub ${ }^{3}$, Michael Andreeff ${ }^{2}$, John C. Reed ${ }^{6}$ and Wei Zhang ${ }^{1,4,7}$

${ }^{1}$ Department of Neuro-Oncology, The University of Texas MD Anderson Cancer Center, 1515 Holcombe Blvd., Houston, Texas 77030, USA

2 Department of Hematology, The University of Texas MD Anderson Cancer Center, 1515 Holcombe Blvd., Houston, Texas 77030, USA

3 Department of Immunology, The University of Texas MD Anderson Cancer Center, 1515 Holcombe Blvd., Houston, Texas 77030, USA

${ }^{4}$ Department of Tumor Biology, The University of Texas MD Anderson Cancer Center, 1515 Holcombe Blvd., Houston, Texas 77030, USA

${ }^{5}$ The Second Department of Internal Medicine, Mie University School of Medicine, Tsu, Mie Prefecture, Japan

${ }^{6}$ The Burnham Institute, La Jolla, California 92037, USA

7 corresponding author: Wei Zhang, Department of Neuro-Oncology, Box 316, The University of Texas MD Anderson Cancer Center, 1515 Holcombe Blvd., Houston, Texas 77030. tel: (713) 792-3778; fax: (713) 745-1183; e-mail:12507vl@audumla.mdacc.tmc.edu.

Received 10.7.97; revised 1.12.97; accepted 4.3.98

Edited by D. Green

\begin{abstract}
In this study, we examined the effects of radiation and ara-C on induction of apoptosis and on the apoptosis-promoting genes p53, Bax and Fas/APO-1, in BV173 human leukemia cells, which harbor the wild-type p53 gene. It has been reported that p53 upregulates Fas/APO-1 and Bax expression. Both irradiation and ara-C treatment resulted in apoptosis and induction of p53 proteins within hours. The Bax gene was activated in irradiated and ara-C-treated BV173 cells, but Fas/APO-1 was induced only in irradiated BV173 cells. Radiation and ara-C treatment did not induce Bax or Fas/APO-1 protein expression in p53-null HL60 cells. Radiation weakly induced Fas/APO-1 expression in KBM-7 cells, which harbor a partially defective p53 gene. Both HL60 and KBM-7 cells are more resistant to radiation- and ara-Cinduced apoptosis than BV173 cells. These results suggest that functional p53 is necessary for the activation of Bax and Fas/APO-1 expression. However, elevated p53 protein is not sufficient to activate Fas/APO-1 gene expression in ara-Ctreated cells. Using two-dimensional gel electrophoresis, we found that the p53 proteins in irradiated and ara-C-treated BV173 cells have different isoelectric points; they converged to a single isoelectric point after in vitro treatment with phosphatase. These results suggest that different genotoxic treatments cause different phosphorylations of p53, which may account for the different levels of activation of Fas/APO1 expression.
\end{abstract}

Keywords: p53 phosphorylation; apoptosis; irradiation; ara-C

Abbreviations: SDS-PAGE, sodium dodecylsulfate-polyacrylamide gel electrophoresis; GAPDH, glyceraldehyde-3-phosphatedehydrogenase; ISEL, in situ end labeling

\section{Introduction}

Programmed cell death, or apoptosis, is an important cellular process that regulates normal homeostasis. Abnormally blocked cell death is one of the hallmarks of cancer. The effectiveness of radiotherapy and chemotherapy may rely on their abilities to induce apoptosis in tumor cells. The status of the tumor suppressor gene p53 has emerged as a key determinant for the responsiveness of tumor cells to these treatments. Stabilization and elevation of the steady-state levels of the wild-type p53 protein occur in response to radiation or DNA-damaging agents and result in apoptosis in some tumor cells (Clarke et al, 1993; Lowe et al, 1993a,b; Radinsky et al, 1994; Ramqvist et al, 1993; Shaw et al, 1992; Yonish-Rouach et al, 1991). Wild-type p53 governs cellular activities by regulating downstream genes that control various cellular pathways (Baak et al, 1993; El-Deiry et al, 1993; Kastan et al, 1992; Kuerbitz et al, 1992; Owen-Schaub et al, 1995). Two genes involved in the apoptosis signal transduction pathway have been shown to be regulated by p53. It has been demonstrated that $\mathrm{p} 53$ activates the expression of the Bax gene, a member of the Bcl-2 family (Miyashita et al, 1994b; Selvakumaran et al, 1994; Zhan et al, 1994), through a specific DNA-responsive element (Miyashita et al, 1994a; Miyashita and Reed, 1995). The product of the Bcl-2 gene promotes cell survival and inhibits apoptosis (Korsmeyer, 1992; Sentman et al, 1991; Strasser et al, 1991), and it has been proposed that the Bax gene product accelerates apoptosis (Boise et al, 1993; Oltvai et al, 1993). The Bax protein can form heterodimeric complexes with Bcl-2, and the relative levels of Bax and $\mathrm{Bcl}-2$ are believed to be important determinants of cell survival and cell death (Oltvai et al, 1993; Yang and Korsmeyer, 1996). Our recent studies showed that p53 transcriptionally activates the expression of Fas/APO-1 (Owen-Schaub et al, 1995). The cell-surface protein Fas/ APO-1 is a member of the tumor necrosis factor receptor superfamily. Overexpression of Fas/APO-1 or engagement of Fas/APO-1 by its ligand (or agonistic antibody) triggers a signal transduction pathway that leads to apoptosis (Itoh et al, 1991; Oehm et al, 1992; Owen-Schaub et al, 1992; Suda et al, 1993; Trauth et al, 1989).

To further understand the mechanism and role of the p53-Bax/Bcl-2 and p53-Fas/APO-1 pathways in the response of cancer cells to radio- and chemotherapy, we focused on the effects of radiation and ara-C treatment on 
the expression of p53, Bax, and Fas/APO-1 and on cell death in wild-type p53-containing BV173 cells and two other cell lines, KBM-7 and HL60, which harbor defective p53 and no p53, respectively. In BV173 leukemia cells, both radiation and ara-C treatment induced apoptosis, raised the levels of p53 protein, and stimulated Bax expression, whereas radiation but not ara-C induced Fas/ APO-1 expression on the cell surface. These results suggest that elevation of p53 protein, although necessary, is not sufficient to activate Fas/APO-1 expression. Our study of p53 post-translational modification using twodimensional electrophoresis revealed that the p53 protein in irradiated BV173 cells had a different phosphorylation status than that in ara-C-treated cells, which may explain the different transcriptional activation functions observed for p53. Intriguingly, radiation did not induce expression of the Fas/APO-1 ligand in BV173 cells, suggesting that either Fas/APO-1 induction is futile or elevated Fas/APO-1 can function independent of its ligand.

\section{Results}

\section{Induction of apoptosis in BV173 cells by radiation and Ara-C}

BV173 cells ( $p 53 \mathrm{wt} / \mathrm{wt}), \mathrm{KBM}-7$ cells ( $p 53 \mathrm{mt} / \mathrm{mt})$, and HL60 cells $(p 53-/-)$ were exposed to either 5 or 10 Gy irradiation or to 50 or $500 \mathrm{nM}$ ara-C. Apoptosis of these cells was analyzed by ISEL using flow cytometry at different times after treatment. As summarized in Table 1 and shown in Figure 1, both radiation and ara-C treatment caused BV173 cells to exhibit abundant apoptotic and secondary necrotic cells. In comparison, HL60 and KBM-7 cells exhibited fewer apoptotic cells. A detailed time-course study showed that abundant apoptosis (41\%) was detected as early as $4 \mathrm{~h}$ after irradiation in BV173 cells. The difference in sensitivity to ara-C among the three cell lines was lost when high-dose ara- $C$ was used.

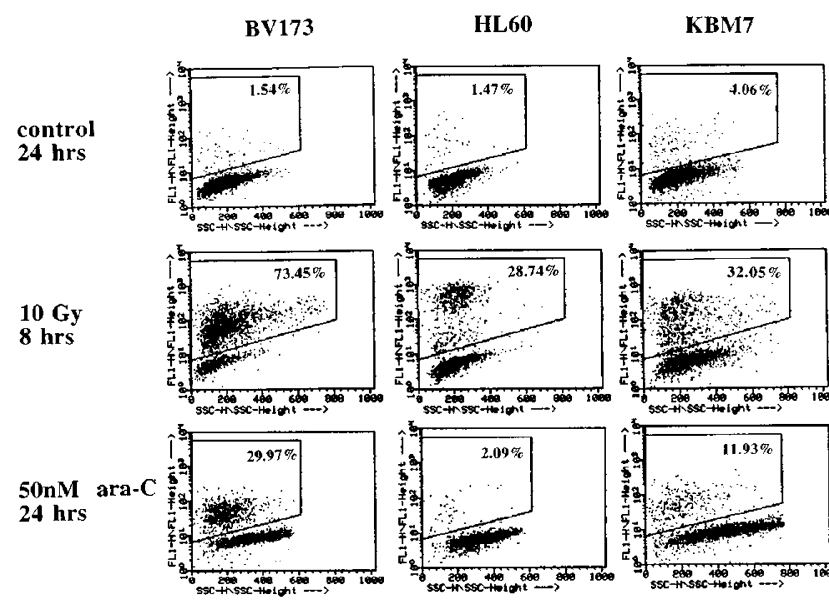

Figure 1 Apoptosis in BV173, HL60, and KMB-7 cells induced by radiation or ara- $C$ treatment. The percentage of apoptotic cells, as analyzed by ISEL flow cytometry assay, are shown in the gated area. The $\mathrm{Y}$-axis shows the fluorescence intensity, which indicates apoptosis; the $\mathrm{X}$-axis shows the sidescattered light intensity
Treatment with high-dose ara-C $(500 \mathrm{nM})$ resulted in abundant apoptosis in HL60 cells $(90.8 \%$ at $48 \mathrm{~h}$ after exposure) and KBM-7 cells (67.3\% at $48 \mathrm{~h}$ after exposure). Apoptotic cells were visualized and confirmed by the presence of morphological features such as nuclear condensation and breakage and cell shrinkage (data not shown).

\section{Effect of radiation and ara-C treatment on the protein levels of $\mathrm{p} 53$ and expression of Fas/APO-1, Bax and $\mathrm{Bcl}-2$}

Our previous studies established the identities of p53 on Western blotting and Fas/APO-1 in flow cytometry assay (Kobayashi et al, 1995). The Bax or Bcl-2 expression vector was transfected into K562 or Jurkat cells. Two days after transfection, Bax and Bcl-2 proteins were analyzed by Western blotting. Parental Jurkat cells contained only low levels of the Bax protein, whereas increased amounts of Bax were detected in Bax-transfected Jurkat cells (Figure 2A). In Bax-transfected K562 cells, the original form of Bax, which we named $\operatorname{Bax}(\mathrm{L})$, increased, and a smaller form of Bax, which we named $\operatorname{Bax}(\mathrm{S})$, appeared (Figure 2A). Bcl-2 protein expression was very low in K562 cells but became easily detected after transfection with Bcl-2-pCl-neo (Figure 2A).

Consistent with previous findings (Kuerbitz et al, 1992; Lowe et al, 1993b), p53 protein levels were elevated rapidly in BV173 cells after irradiation (Figure 2B) or treatment with ara-C (Figure $2 \mathrm{C}$ ). In BV173 cells, $8 \mathrm{~h}$ after irradiation or $24 \mathrm{~h}$ after ara-C exposure, the $\operatorname{Bax}(\mathrm{S})$ band was induced dose dependently and at later time points was enhanced, with little change in the level of $\operatorname{Bax}(\mathrm{L})$ (Figure 2B). A detailed time-course study showed that the $\operatorname{Bax}(\mathrm{S})$ band became detectable after $6 \mathrm{~h}$ of irradiation (data not shown). In p53-null HL60 cells or KBM-7 cells, which have a mutant p53, only small amounts of $\operatorname{Bax}(S)$ were detected after $24-$ $48 \mathrm{~h}$ of treatment (Figure $2 \mathrm{~B}$ and $\mathrm{C}$ ). The $\mathrm{Bcl}-2$ protein did not change after irradiation in all three cell lines (Figure 2B) and was only weakly induced $48 \mathrm{~h}$ after ara-C treatment in

Table 1 Apoptotic cell population after radiation or ara-C treatment

\begin{tabular}{lcccc}
\hline Dose of & Hours after & \multicolumn{3}{c}{ Apoptotic cells (\%) } \\
radiation or ara-C & treatment & BV 173 & HL 60 & KMB-7 \\
\hline Control & 0 & 2.56 & 1.53 & 5.72 \\
& 24 & 1.54 & 1.47 & 4.06 \\
& 48 & 2.53 & 2.28 & 5.39 \\
5-Gy & & & & \\
& 8 & 45.95 & 11.24 & 26.34 \\
& 24 & $33.71^{\mathrm{a}}$ & 28.05 & 27.14 \\
$10 \mathrm{~Gy}$ & & & & \\
& 8 & 73.45 & 28.74 & 32.05 \\
& 24 & $57.18^{\mathrm{a}}$ & 47.50 & 43.65 \\
$50 \mathrm{nM}$ & & & & \\
& 8 & 13.02 & 1.75 & 6.16 \\
& 24 & 29.97 & 2.09 & 11.93 \\
$500 \mathrm{nM}$ & 48 & $64.53^{\mathrm{a}}$ & 5.39 & 16.18 \\
& 24 & $\mathrm{~b}$ & 27.43 & 34.34 \\
& 48 & $\mathrm{~b}$ & 90.79 & 67.30 \\
\hline
\end{tabular}

aMany cell showed secondary necrosis and lysis

${ }^{b}$ Extensive cell lysis was observed 
A

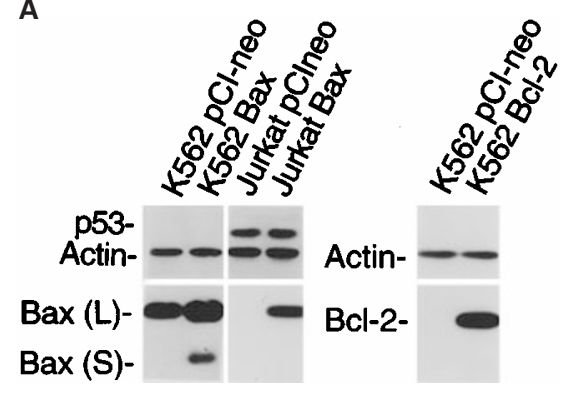

C
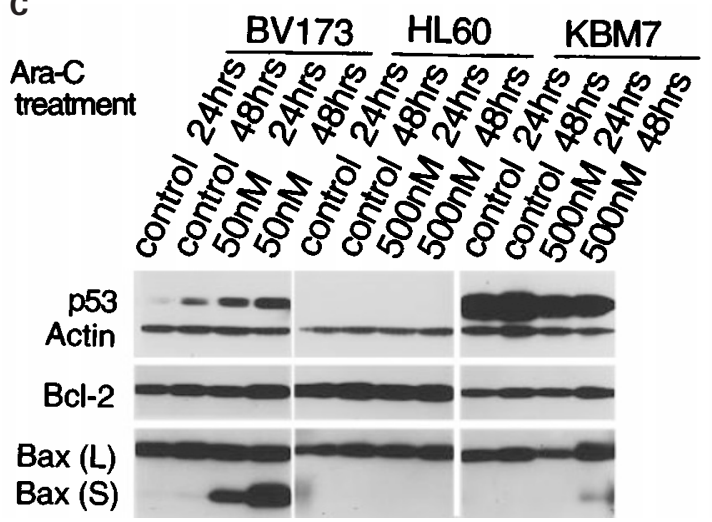

B

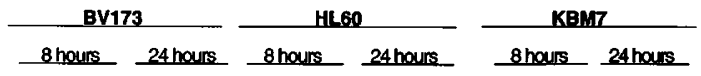

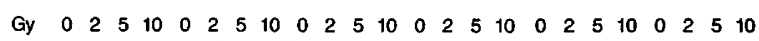

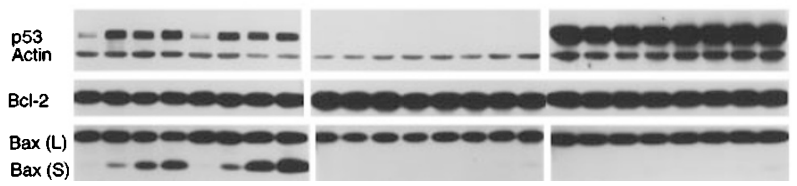

D

Pulse

$\begin{array}{lllll}\text { Chase (h) } & 0 & 6 & 12 & 24\end{array}$

$\operatorname{Bax}(\mathbf{L})$

Bax (S)

Figure 2 Expression of $\mathrm{p} 53, \mathrm{Bax}$, and Bcl-2 protein in cells irradiated or treated by ara-C. (A) K562 and Jurkat cells were transfected with pCl-neo, Bax-pCl-neo, or Bcl-2-pCl-neo vector by electroporation. Forty-eight hours later, proteins were extracted and analyzed for expression of p53, actin, Bax, and Bcl-2 on Western blots using specific antibodies. (B) BV173, HL60, and KBM-7 cells were exposed to radiation at three doses. Proteins were extracted 8 or $24 \mathrm{~h}$ after radiation and analyzed for expression of p53, Bcl-2, Bax and actin. (C) BV173, HL60, and KBM-7 cells were exposed to 50 or $500 \mathrm{nM}$ ara-C for 24 or $48 \mathrm{~h}$, and proteins were extracted and analyzed by Western blotting for levels of p53, Bcl-2, Bax, and actin protein. (D) BV173 cells were irradiated, metabolically labeled with ${ }^{35}$ Smethionine and pulse chased with unlabeled methionine for the periods indicated. Proteins were isolated and immunoprecipitated with anti-Bax antibody. The precipitates were analyzed by SDS-PAGE and autoradiography

BV173 cells (Figure 2C). To further establish the identity of Bax(S), 5 Gy-irradiated BV173 cells were metabolically labeled with ${ }^{35} \mathrm{~S}$-methionine for $2 \mathrm{~h}$ and pulse-chased with unlabeled methionine for different periods of time. Bax antibody was used to immunoprecipitate $\operatorname{Bax}(\mathrm{L})$ and $\operatorname{Bax}(S)$. We found that a decrease in $\operatorname{Bax}(L)$ reciprocally accompanied an increase in $\operatorname{Bax}(S)$, suggesting that $\operatorname{Bax}(S)$ is a cleaved product of the $\operatorname{Bax}(\mathrm{L})$ form (Figure 2D). Production of $\operatorname{Bax}(\mathrm{S})$ is dependent on the dose of radiation and ara-C (Figure 2B and $\mathrm{C}$ ) and on the extent of apoptosis induced by these treatments.

Next we analyzed the expression of surface Fas/APO-1 by flow cytometry. As shown in Figure $3 \mathrm{~A}$, surface Fas/ APO-1 was strongly induced in BV173 cells by 10 Gy radiation. Surprisingly, Fas/APO-1 was not significantly induced in ara-C-treated BV173 cells (Figure 3A), although p53 protein was induced (Figure 2B). Induction of surface Fas/APO-1 was not detected in HL60 or KBM-7 cells after either treatment (data now shown). We also analyzed the protein expression of p21/WAF1/Cip1, a downstream target gene of p53 (El-Deiry et al, 1993). In BV173 cells, p21/WAF1/Cip1 was induced by radiation, but not by ara-C (Figure $3 \mathrm{~B}$ ). In irradiated HL60 cells and
KBM-7 cells, p21/WAF1/Cip1 was not induced (data not shown). These findings showed that elevated p53 in araC-treated BV173 cells was not functional in activating the expression of downstream genes p21/WAF1/Cip1 and Fas/APO-1.

To determine whether the protein induction reflected induction at the mRNA level, total cellular RNA was isolated from the treated cells and analyzed for the levels of $B a x$ and Fas/APO-1 mRNA. The levels of GAPDH were used as an internal control for quantitation. mRNA levels of both Bax and Fas/APO-1 were increased in irradiated BV173 cells (Figure 4A). In BV173 cells treated with ara-C, Bax mRNA was also induced (Figure 4B). In contrast, the Bax mRNA level was decreased in KBM-7 and HL60 cells for reasons not yet known. Consistent with the data shown in Figure $3 \mathrm{~B}$, in BV173 cells, a very high level of Fas/APO-1 mRNA was induced after radiation (Figure 4A), whereas very weak Fas/APO-1 mRNA was induced after ara-C treatment (Figure 4B). In irradiated or ara-C-treated HL60 cells, Fas/APO-1 mRNA was barely induced (Figure 4), and in irradiated or ara-C-treated KBM-7 cells, Fas/APO-1 mRNA was relatively weakly induced (Figure 4) compared with the induction by irradiation in BV173 cells. Interest- 
A
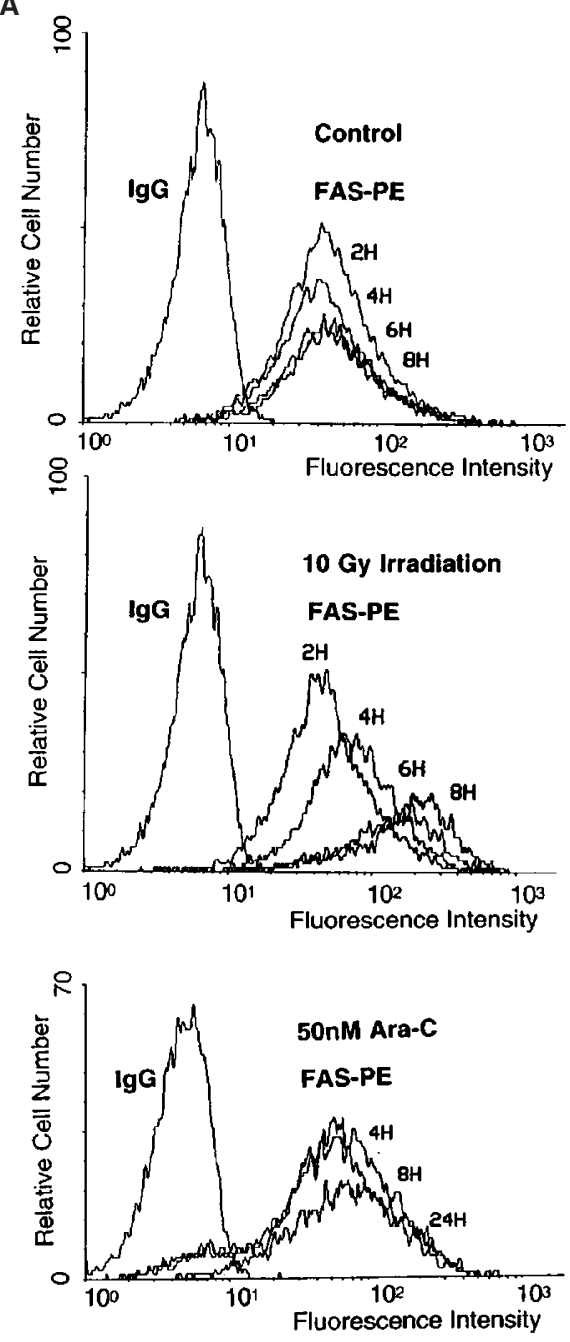

B

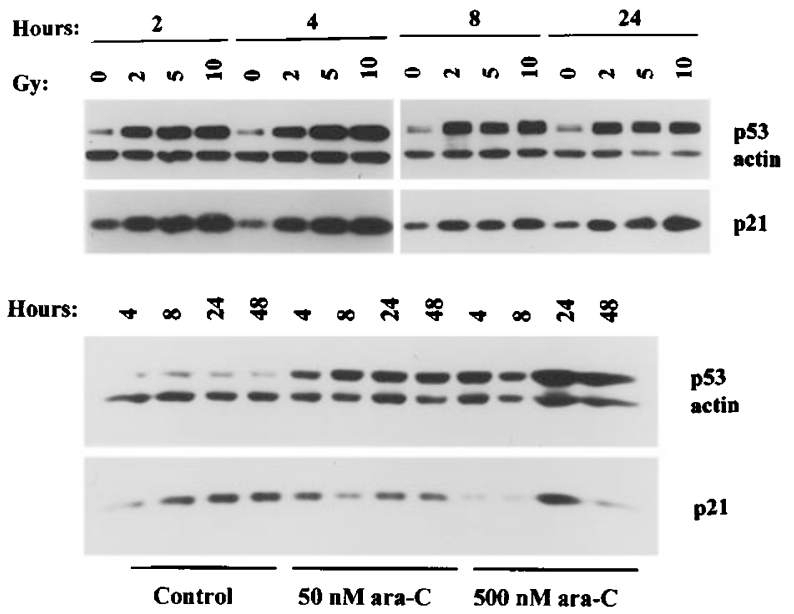

Figure 3 Detection of surface Fas/APO-1 protein expression by flow cytometry and of $\mathrm{p} 21 / \mathrm{WAF} 1 / \mathrm{Cip} 1$ expression by Western blotting after irradiation or ara- $\mathrm{C}$ treatment. (A) The $\mathrm{Y}$-axis shows the relative cell number and the $\mathrm{X}$-axis the fluorescence intensity of Fas/APO-1 staining. Mouse IgG was used as a control for Fas/APO-1 antibody. (B) BV173 and HL60 cells were exposed to radiation or ara-C. Proteins were analyzed for expression of p21/ WAF1/Cip1

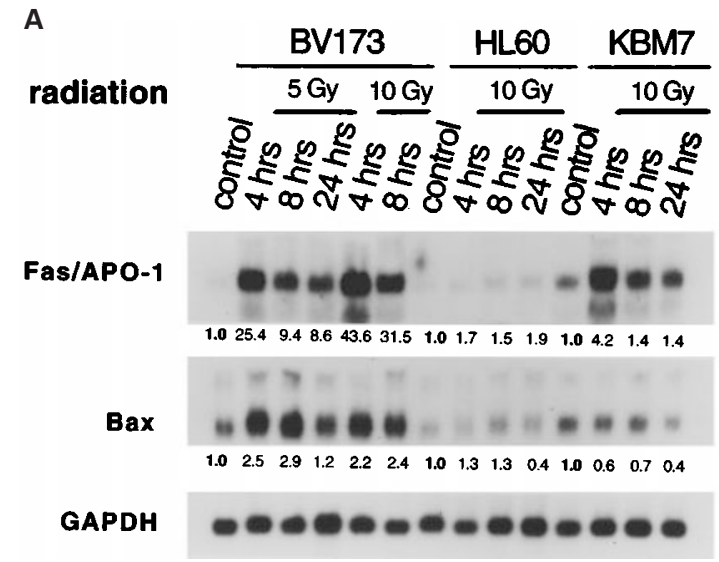

B

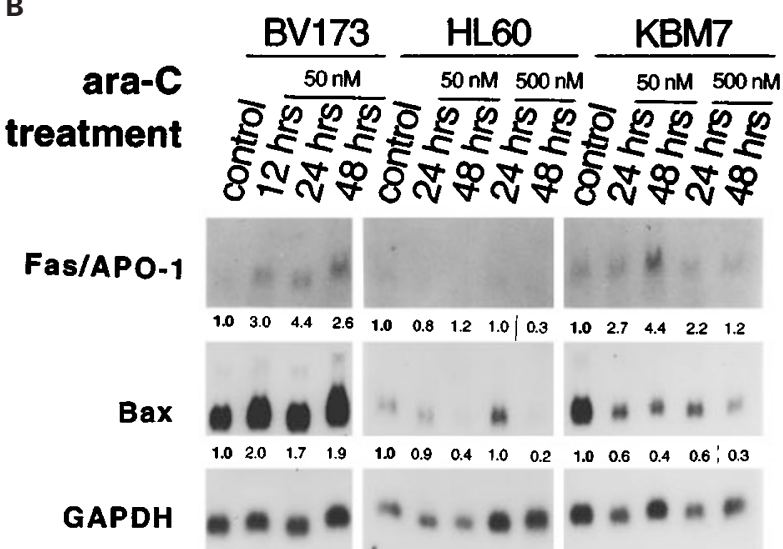

Figure 4 Expression of Bax and Fas/APO-1 mRNAs in cells irradiated or treated with ara-C. (A) Total RNA was isolated from cells 4,8 , or $24 \mathrm{~h}$ after radiation, and the levels of $B a x$ and Fas/APO-1 were analyzed by Northern blotting using cDNA for Bax or Fas/APO-1 as a probe. (B) Total RNA was isolated from ara-C-treated BV173, HL60, and KBM-7 cells; Fas/APO-1 and Bax mRNA levels were analyzed by Northern blotting. A total of $15 \mathrm{mg}$ RNA was loaded in each lane. The level of GAPDH mRNA was also analyzed as a control of RNA loading. The intensities of the Fas/APO-1, Bax, and GAPDH bands on the autoradiograph were scanned using a densitometer and the levels of Fas/APO-1 and Bax were normalized against that of GAPDH. The control value was designated as 1.0, and the relative levels of Fas/APO-1 and Bax were calculated and are shown under each band

ingly, a fourfold induction of Fas/APO-1 mRNA was not sufficient to generate enough surface Fas/APO-1 protein to be detected by flow cytometry, probably reflecting the relatively low sensitivity of flow cytometry. Bax mRNA induction was not observed in irradiated or ara-C-treated HL60 and KBM-7 cells (Figure 4).

To investigate whether the Fas/APO-1 pathway contributes to irradiation-induced apoptosis of BV173 cells, we analyzed the levels of Fas/APO-1 ligand expression on Northern blotting because Fas/APO-1 may need its ligand to be fully active. No induction of ligand expression was detected (data not shown). We then tested whether the agonistic Fas/APO-1 antibody (APO-1, Kamiya Biomedical Co.) could engage the Fas/APO-1 receptor induced by radiation and further sensitize the BV173 cells to apoptosis. The result was again negative (data not shown), suggesting 
that the Fas/APO-1 pathway was not active in radiationinduced apoptosis in BV173 cells. As a positive control, the agonistic Fas/APO-1 antibody induced drastic apoptosis in Jurkat cells.

\section{Distinct phosphorylation of p53 protein in irradiated and ara-c-treated BV173 cells}

The above results posed two problems to our previous findings that wild-type but not mutant p53 activates Fas/APO1 expression (Owen-Schaub et al, 1995). First, Fas/APO-1 was also induced in mutant p53-containing KBM-7 cells. Our previous studies showed that the p53 mutant in KBM7 cells retains the ability to bind DNA (Zhang et al, 1993, 1995). This mutant, therefore, is only partially defective, which may explain its weak ability to activate Fas/APO-1. Second, elevated p53 in ara-C-treated BV173 cells did not markedly

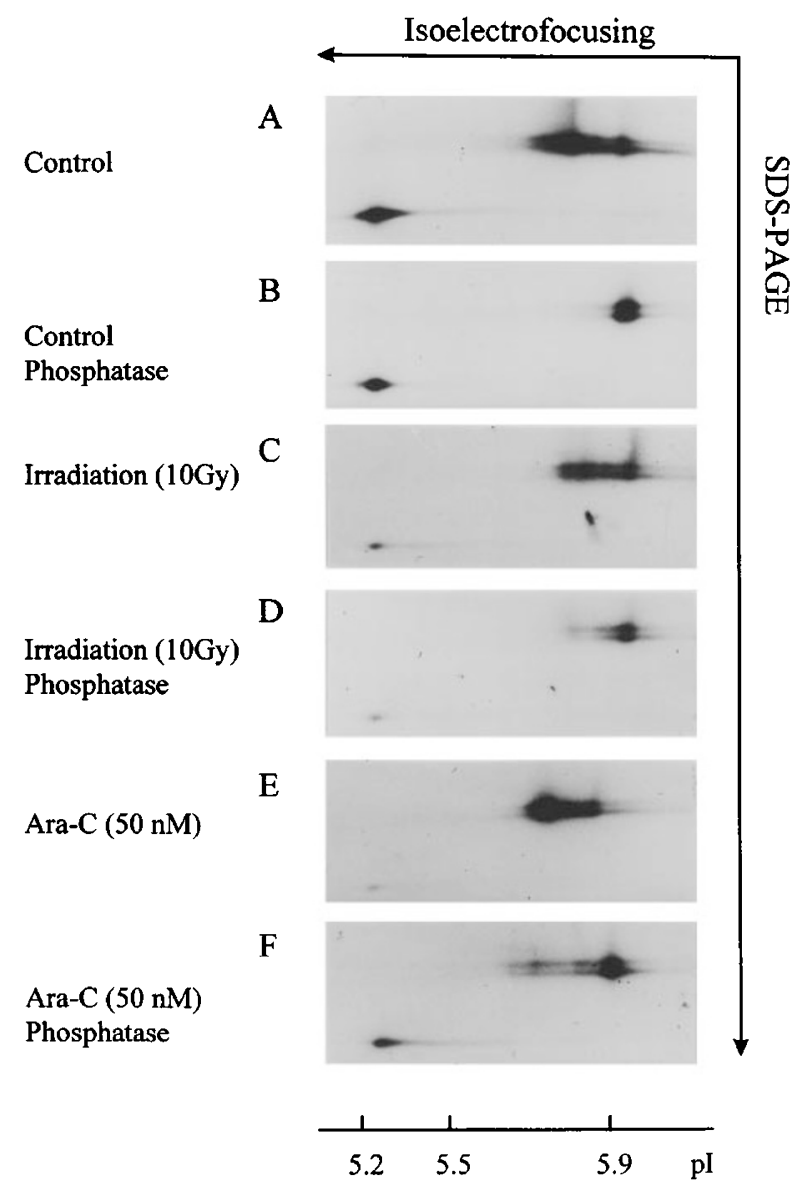

Figure 5 Phosphorylation of p53 protein in irradiated and ara-C-treated BV173 cells as analyzed by two-dimensional gel electrophoresis. Six hours after irradiation or ara-C treatment, BV173 cells were labeled with ${ }^{35} \mathrm{~S}$ methionine for $2 \mathrm{~h}$. Total proteins were isolated, and p53 proteins were immunoprecipitated with a mixture of the p53 antibodies PAb421 and PAb1801. Half the immunoprecipitates were treated with phosphatase. Then the p53 precipitates with or without phosphatase treatment were analyzed in a two-dimensional gel electrophoresis. The two mobilities of p53 on SDSPAGE represent the two polymorphic forms of p53 and serves as a reference point activate Fas/APO-1 expression. To understand the molecular basis for the second problem, we hypothesized that the p53 proteins in the irradiated and ara-C-treated cells had different posttranslational modifications. To test this, we labeled the irradiated and ara-C treated BV173 cells (after $6 \mathrm{~h}$ of treatment) with ${ }^{35} \mathrm{~S}$-methionine, and then the immunoprecipitated p53 proteins were subjected to two-dimensional gel electrophoresis, with one dimension separated by isoelectric points (isoelectrofocusing gel) and another dimension by size (SDS - PAGE). On the SDS - PAGE dimension, p53 proteins in BV173 cells exhibited two different mobilities. We showed previously that these two forms represent the two polymorphic forms of p53 at codon 73 (Zhang et al, 1992). Along the isoelectrofocusing dimension, p53 in irradiated BV173 cells existed as multiple forms, with a pl spanning from 5.75-5.95 (Figure 5C). In comparison, in ara-C-treated BV173 cells, the isoelectric points of p53 proteins shifted to lower values (Figure 5E). Gels were aligned in reference to the molecular weight marker and the nonspecific protein product at pl 5.2 observed on the gel (Figure 5A-F). Because phosphorylation is the key factor affecting the pl of proteins, we assume that p53 proteins with different pls represent p53 proteins with different phosphorylation status. To test this hypothesis, we treated the immunoprecipitated p53 protein with phosphatase and then analyzed the treated p53 proteins on twodimensional gel electrophoresis. This treatment converted most of the p53 proteins to a common form (Figure 5B, D and $\mathrm{F})$, confirming that phosphorylation was the modification that resulted in the different $\mathrm{pl}$ values fo p53 proteins from irradiated and ara-C-treated cells. p53 proteins in both control and ara-C-treated cells appeared to be more phosphorylated than that in irradiated BV173 cells. In contrast, p53 mutant proteins with virtually identical pl values were identified in control, radiation-treated and ara-C-treated KBM-7 cells (Figure 6). We attempted to identify the specific phosphorylation sites using conventional phosphopeptide

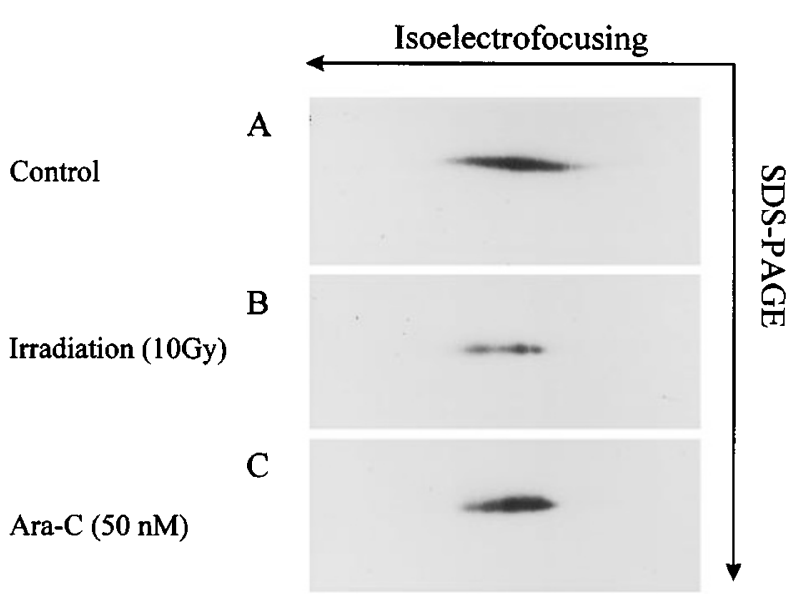

Figure 6 Patterns of isoelectric points of the p53 mutant protein in KBM-7 cells after irradiation or ara-C treatment. Six hours after irradiation or ara- $C$ treatment, KBM-7 cells were labeled with ${ }^{35} \mathrm{~S}$-methionine for $2 \mathrm{~h}$. Total proteins were isolated, and p53 proteins were immunoprecipitated with a mixture of the p53 antibodies PAb421 and PAb1801. The precipitates were analyzed in a two-dimensional gel electrophoresis 
mapping and sequencing. However, our preliminary studies showed that metabolic labeling with ${ }^{32} \mathrm{P}$ subjected cells to radiation strong enough to abolish the difference in the pls of p53 in the irradiated and ara-C-treated cells. Other nonisotopic approaches are needed to identify the specific sites of p53 phosphorylation.

\section{Discussion}

Radiation and chemotherapy are two major modalities for eradicating cancer cells. Many factors affect the response of cells to these treatments. The status of the $p 53$ gene has been shown to be a crucial element in the sensitivity of hematopoietic malignant cells to treatment-induced apoptosis. Previous studies have shown that p53 protein levels are elevated by DNA-damaging treatment, and p53 can transcriptionally activate two genes that may promote apoptosis, Bax (Miyashita et al, 1994a; Selvakumaran et al, 1994; Zhan et al, 1994) and Fas/APO-1 (Owen-Schaub et al, 1995). In this study, we investigated the effect of radiation and ara- $C$ on the transcriptional activation of Bax and Fas/APO-1 in a wild-type p53-containing cell line, BV173. Both treatments elevated p53 protein levels to a similar extent and induced apoptosis; however, the expression patterns of Fas/APO-1 were different. Fas/APO-1 was strongly induced by radiation but only weakly induced in ara-C-treated cells. Although the role of Fas/APO-1 in radiation-induced BV173 cells is not apparent because no Fas/APO-1 ligand was expressed, these results do demonstrate that radiation and ara-C elicit different molecular events in the activation of apoptosis and that elevated p53 protein is not sufficient to activate the Fas/APO-1 gene. Similarly, ara-Cinduced p53 protein also failed to activate expression of the cell cycle modulator p21/WAF1/Cip1. Nevertheless wild-type p53 is necessary for maximal Bax and Fas/APO-1 induction because they were not induced in p53-null HL60 cells and Fas/APO-1 was only weakly induced in irradiated KBM-7 cells, which contain a partially active p53 mutant.

Our results showed that the function of p53 protein is also determined at the epigenetic level in drug-treated cells. Using two-dimensional gel electrophoresis, we analyzed the p53 proteins isolated from irradiated or ara-C-treated BV173 cells. Different patterns in isoelectric points of p53 proteins were observed. In contrast, in KBM-7 cells virtually identical patterns in the isoelectric points of mutant p53 were observed after either radiation or ara-C treatment. Because p53 is a phosphorylated protein and phosphorylation has been shown to modulate the functions of p53 (Friscella et al, 1993; Lees-Miller et al, 1992; Milne et al, 1995; Zhang et al, 1994b), we hypothesized that the p53 proteins in irradiated and ara-C-treated BV173 cells were differentially phosphorylated. The experiments with phosphatase confirmed this hypothesis. The lower pl values of p53 proteins in ara-C-treated BV173 cells indicated that this treatment induced more extensive phosphorylation. Unique phosphorylation of p53 induced by ara-C may be the basis for its inability to transactivate Fas/APO-1. These results provide further evidence that phosphorylation is an important mechanism in the functional regulation of $p 53$, especially under genotoxic stress conditions. Our initial attempt to identify the specific phosphorylation sites using the conventional ${ }^{32} \mathrm{P}$ isotopic labeling approach failed because the labeling itself stabilized p53 protein and caused extensive cell death, which may have resulted in further change in the phosphorylation status of p53. Thus, a nonisotopic approach is needed to study p53 phosphorylation. By the same token, although ${ }^{35} \mathrm{~S}$-methionine labeling was not strong enough to diminish the difference between the effects of ara-C and radiation on p53, the results need to be further validated in the future.

This study also revealed some interesting aspects of Fas/APO-1's functional role and of Bax metabolism during irradiation- and ara-C-induced apoptosis. Both Fas/APO-1 and Bax proteins were induced in apoptotic BV173 cells by irradiation, whereas Fas/APO-1 protein was not induced in apoptotic BV173 cells by ara-C. This result showed that Fas/APO-1 was not required in ara-C-induced, p53dependent apoptosis. In irradiated BV173 cells, although Fas/APO-1 was strongly induced, the Fas/APO-1 ligand was not produced. This result suggests either that elevated Fas/APO-1 can participate in apoptosis induction indpendent of its ligand or that Fas/APO-1 induction is futile in this system. An inactive Fas/APO-1 pathway had also been observed previously in K562 cells, in which Fas/APO-1 was induced by a temperature-sensitive mutant of human p53 (Kobayashi et al, 1995). It is possible that Bax or other unidentified factors mediate p53-induced apoptosis in irradiated BV173 cells.

Our experiments detected a shortened form of Bax, $\operatorname{Bax}(\mathrm{S})$, which was associated with the presence of apoptotic cells in the culture. Because $\operatorname{Bax}(S)$ was first detected in irradiated BV173 cells $6 \mathrm{~h}$ after irradiation, which was $2 \mathrm{~h}$ after significant levels of apoptotic cells $(41 \%)$ were detected, it is not very likely that $\operatorname{Bax}(S)$ is an active form of Bax in apoptosis induction. A more likely possibility is that $\operatorname{Bax}(\mathrm{S})$ is a specifically cleaved product of Bax created during apoptosis. Cleavage of other proteins during apoptosis was also reported (Liu et al, 1996; Wang et al, 1995; 1996). It would be interesting to investigate whether ICE or ICE-related protease is responsible for Bax cleavage, whether $\operatorname{Bax}(\mathrm{S})$ plays any active role in the apoptotic process, and whether $\operatorname{Bax}(S)$ may serve as a useful marker for a later stage of apoptosis.

\section{Materials and Methods}

\section{Cell culture}

K562, Jurkat and HL60 cell lines were obtained from American Type Culture Collection (Rockville, MD); the KBM-7 cell line was provided by Dr B Andersson (The University of Texas MD Anderson Cancer Center); the BV173 cell line was derived from a patient with chronic myelogenous leukemia (Pegoraro et al, 1983; Th'ng et al, 1987). K562, Jurkat, HL60 and KBM-7 cells were maintained in RPMI 1640 medium supplemented with $10 \%$ fetal calf serum in a $37^{\circ} \mathrm{C}$ incubator containing $5 \% \mathrm{CO}_{2}$ and $95 \%$ air; $5 \%$ fetal calf serum was routinely used to maintain BV 173 cells. VB173 cells contain the wild-type p53 gene, KBM-7 cells contain a homozygous p53 mutant at codon 215 (Zhang et al, 1993), and the p53 gene is deleted in HL60 cells (Wolf and Rotter, 1985). 


\section{Radiation and ara-C treatment}

The radiation source was provided by a model E-0103 irradiator (U.S. Nuclear $\mathrm{Co}$.). ara-C treatment was performed by continuous exposure of cells to $50 \mathrm{nM}$ cytosine b-D-arabinofuranoside (ara-C) (Sigma).

\section{DNA transfection}

$\mathrm{Bax}$ and $\mathrm{BCl}-2$ expression vectors were prepared by inserting $\mathrm{Bax}$ or $B c l-2$ cDNA into the $E c o R I$ cloning site of the $\mathrm{pCl}$-neo vector (Promega). Electroporation was used to transfect expression plasmids into K562 cells and Jurkat cells, under the conditions described previously (Maxwell and Maxwell, 1988; Ulrich and Ley, 1990). To ensure stable transfection, cells were selected in medium

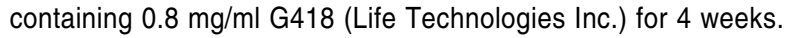

\section{Western blotting}

Total cellular protein was extracted and analyzed by sodium dodecylsulfate-polyacrylamide gel electrophoresis (SDS-PAGE) as described previously (Stadler et al, 1994; Zhang et al, 1993). After being transferred to an Immobilon membrane (Millipore), the proteins were incubated overnight with antibodies against Bcl-2 (Dako Co.), Bax (Krajewski et al, 1994), p53 (Ab-6, Oncogene Science), and actin (Ab-1, Oncogene Science). The levels of protein were analyzed using the enhanced chemiluminescence system (Amersham Corp.) according to the manufacturer's instructions.

\section{Northern blotting}

Total cellular RNA was isolated using TRI reagent (Molecular Research Center, Inc.) and Northern blot analysis was performed as described previously (Owen-Schaub et al, 1995). The cDNA probes used were (i) a $1.3 \mathrm{~kb}$ Pstl gene fragment of glyceraldehyde-3phosphate-dehydrogenase (GAPDH); (ii) a $595 \mathrm{~kb}$ EcoRl fragment of human Bax, and (iii) a $1.4 \mathrm{~kb} E c o R I$ fragment of human Fas/APO-1. The intensities of Bax, Fas/APO-1, and GAPDH (linear range) on blots were scanned using a densitometer. The levels of Bax and Fas/APO-1 were normalized against that of GAPDH.

\section{Flow cytometry}

To analyze the Fas/APO-1 expression on cells, the phycoerythrinconjugated anti-Fas monoclonal antibody (CD95, PharMingen) was used. Phycoerythrin-conjugated mouse $\lg _{1}$ with irrelevant specificity was used as negative control. A minimum of $1 \times 10^{6}$ cells was incubated with each monoclonal antibody for $30 \mathrm{~min}$ at $4^{\circ} \mathrm{C}$. After two washings, cells were resuspended in $500 \mathrm{ml}$ of cold phosphatebuffered saline. Flow cytometric acquisition was immediately performed on a FACScan instrument (Becton Dickinson) and analyzed with Lysisll software (Becton Dickinson).

In situ end labeling (ISEL) was used to measure apoptosis. To quantitate the number of apoptotic cells, we used a method of ISEL of DNA strand breaks (Gorczyca et al, 1993), which was slightly modified from a previously described method (Kobayashi et al, 1995).

\section{Immunoprecipitation, phosphate treatment and two-dimensional gel analysis}

After irradiation or ara-C treatment, cells were labeled with ${ }^{35} \mathrm{~S}$ methionine-containing medium for $2 \mathrm{~h}$ as described (Zhang et al, 1994a). Protein was extracted with Nonidet P40 (NP40) lysis buffer containing $0.5 \mathrm{mg} / \mathrm{ml}$ aprotinin, $0.1 \mathrm{mg} / \mathrm{ml}$ pepstatin $\mathrm{A}, 1 \mathrm{mM}$ DL- dithiothreitol, $1 \mathrm{mM}$ phenylmethylsulfonyl fluoride, $10 \mathrm{mM}$ sodium fluoride, and $12.5 \mathrm{mM}$ sodium pyrophosphate. Protein extract was precleaned with mouse IgG and protein $\mathrm{G}$ agarose and immunoprecipitated with p53 antibodies (PAb421 and PAb1801, Oncogene Science). For phosphatase treatment, each protein sample on protein $G$ agarose was incubated with 66 DEA units of bovine intestinal alkakine phosphatase (Sigma) and 0.8 units of sweet potato acid phosphatase (Sigma) in $50 \mathrm{mM}$ Tris buffer ( $\mathrm{pH} 7.4)$ at $37^{\circ} \mathrm{C}$ for $1 \mathrm{~h}$. Immunoprecipitated protein samples that had or had not undergone phosphatase treatment were resuspended with standard urea solubilization buffer consisting of $54 \%$ urea, $4 \%$ NP- $-40,2 \%$ ampholyte ( $\mathrm{pH} 3-10$, Sigma), and 2\% 2-mercaptoethanol. Isoelectrofocusing gel solution consisted of $8.25 \mathrm{~g}$ urea, $6.0 \mathrm{ml} \mathrm{H}$ ampholyte (pH 3-10), and $2.0 \mathrm{ml} \mathrm{30 \%} \mathrm{acrylamide/1.8 \%} \mathrm{bisacryla-}$ mide; it was polymerized with $10 \mathrm{ml}$ TEMED and $70 \mathrm{ml} 20 \%$ ammonium persulfate. After pre-running for $1 \mathrm{~h}$ at $200 \mathrm{~V}$, protein samples were loaded into tubes and run overnight at $800 \mathrm{~V}$ at room temperature. The gels were then soaked with equilibrating buffer containing SDS for $15 \mathrm{~min}$ at room temperature; SDS-PAGE $(10 \%$ acrylamide) was performed as second-dimension electrophoresis. After SDS-PAGE, gels were fixed, soaked with Amplify (Amersham International), dried and exposed on X-ray film.

\section{Acknowledgements}

This work was partially supported by a BRSG grant from MD Anderson Cancer Center and NIH grants CA67987 and CA55164. Special thanks are extended to Ms. Kathryn Carnes and Leslie Wildrick for their editorial assistance. T. Kobayashi and S. Ruan contributed equally to this work.

\section{References}

Barak Y, Juven T, Haffner R and Oren M (1993). mdm2 expression is induced by wild type p53 activity. EMBO J. 12: 461-468

Boise LH, Gonzalez-Garcia M, Postema CE, Ding L, Lindsten T, Turka L, Mao X, Nunez $G$ and Thompson CB (1993) bcl-x, a bcl-2-related gene that functions as a dominant regulator of apoptotic cell death. Cell 74: 597-608

Clarke AR, Purdie CA, Harrison DJ, Morris RG, Bird CC, Hooper ML and Wyllie AH (1993) Thymocyte apoptosis induced by p53-dependent and independent pathways. Nature 362: 849-852

El-Deiry WS, Tokino T, Velculescu VE, Levy DB, Parsons R, Trent JM, Lin D, Mercer WE, Kinzler KW and Vogelstein B (1993) WAF1, a potential mediator of p53 tumor suppression. Cell 75: 817-825

Fiscella M, Ullrich SJ, Zambrano N, Shields MT, Lin D, Lees-Miller SP, Anderson CW, MercerWE and Appella E (1993) Mutation of the serine 15 phosphorylation site of human $p 53$ reduces the ability of $p 53$ to inhibit cell cycle progression. Oncogene 8: $1519-1528$

Gorczyca W, Gong J-P and Darzynkiewicz Z (1993) Detection of DNA strand breaks in individual apoptotic cells by the in situ terminal deoxynucleotidyl transferase and nick translation assays. Cancer Res. 53: 1945-1951

Itoh N, Yonehara S, Ishii A, Yonehara M, Mizushima S, Sameshima M, Hase A, Seto Y and Nagata S (1991) The polypeptide encoded by the cDNA for human cell surface antigen Fas can mediate apoptosis. Cell 66: 233-243

Kastan MB, Zhan Q, El-Deiry WS, Carrier F, Jacks T, Walsh WV, Plunkett BS, Vogelstein B and Fornace AJ (1992) A mammalian cell cycle checkpoint pathway utilizing p53 and GADD45 is defective in ataxia-telangiectasia. Cell 71:587-597

Kobayashi T, Consoli U, Andreeff M, Shiku H, Deisseroth AB and Zhang W (1995) Activation of $\mathrm{p} 21^{\mathrm{WAF} 1 / \mathrm{Cip} 1}$ expression by a temperature-sensitive mutant of human 553 does not lead to apoptosis. Oncogene 11: 2311-2316

Korsmeyer SJ (1992) Bcl-2 initiates a new category of oncogenes: regulators of cell death. Blood 80: 879-886

Krajewski S, Krajewska M, Shabaik A, Miyashita T, Wang HG and Reed JC (1994) Immunohistochemical determination of in vivo distribution of Bax, a dominant inhibitor of Bcl-2. Am. J. Pathol. 145: 1323-1336 
Kuerbitz SJ, Plunkett BS, Walsh WV and Kastan MB (1992) Wild-type p53 is a cell cycle checkpoint determinant following irradiation. Proc. Natl. Acad. Sci. USA 89: $7491-7495$

Lees-Miller SP, Sakaguchi K, Ullrich SJ, Appella E and Anderson CW (1992) Human DNA-activated protein kinase phosphorylation serines 15 and 37 in the aminoterminal transactivation domain of human p53. Mol. Cell. Biol. 12: 5041-5049

Liu X, Kim CN, Yang J, Jemmerson R and Wang X (1996) Induction of apoptotic program in cell-free extracts: requirement for dATP and cytochrome $\mathrm{C}$. Cell 86: $147-157$

Lowe SW, Ruley HE, Jacks T and Housman DE (1993a) p53-dependent apoptosis modulates the cytotoxicity of anticancer agents. Cell 74: 957-967

Lowe SW, Schmitt EM, Smith SW, Osborne BA and Jacks T (1993b) p53 is required for radiation-induced apoptosis in mouse thymocytes. Nature 362: 847-849

Maxwell IH and Maxwell F (1988) Electroporation of mammalian cells with a firefly luciferase expression plasmid: kinetics of transient expression differ markedly among cell types. DNA 7: 557-562

Milne DM, Cambell LE, Cambell DG and Meek DW (1995) p53 is phosphorylated in vitro and in vivo by an ultraviolet radiation-induced protein kinase characteristic of the c-Jun kinase, JNK1. J. Biol. Chem. 270: 5511-5518

Miyashita T, Harigai M, Hanada M and Reed JC (1994a) Identification of a p53dependent negative response element in the bcl-2 gene. CancerRes. 54:31313135

Miyashita T, Krajewski S, Krajewski M, Wang HG, Lin HK, Liberman DA, Hoffman B and Reed JC (1994b) Tumor suppressor p53 is a regulator of bcl-2 and bax gene expression in vitro and in vivo. Oncogene 9: 1799-1805

Miyashita T and Reed JC (1995) Tumor suppressor p53 is a direct transcriptional activator of the human bax gene. Cell 80: 293-299

Oehm A, Behrmann I, Falk W, Pawlita M, Maier G, Klas C, Li-weber M, Richards J, Dhein J, Trauth BC, Ponsting $\mathrm{H}$ and Krammer PH (1992) Purification and molecular cloning of the APO-1 cell surface antigen, a member of the tumor necrosis factor/nerve growth factor receptor superfamily. Sequence identity with the Fas antigen. J. Biol. Chem. 267: 10709-10715

Oltvai ZN, Milliman CL and Korsmeyer SJ (1993) Bcl-2 heterodimerizes in vivo with a conserved homolog, Bax, that accelerates programmed cell death. Cell 74 : $609-619$

Owen-Schaub LB, Zhang W, CusackJC, Angelo LS, Santee SM, Fujiwara T, Roth JA, Deisseroth AB, Zhang W-W, Kruzel E and Radinsky R (1995) Wild-type human p53 and a temperature-sensitive mutant induce Fas/APO-1 expression. Mol. Cell. Biol. 15: 3032-3040

Owen-Schaub LB, Yonehara S, Crump WL III and Grimm EA (1992) DNA fragmentation and cell death is selectively triggered in activated human lymphocytes by Fas antigen engagement. Cell. Immunol. 140: 197-205

Pegoraro L, Matera L, Ritz J, Levis A, Palumbo A and Biagini G (1983) Establishment of a Ph1-positive human cell line (BV173). J. Natl. Cancer Inst. 70: 447-453

Radinsky R, Fidler IJ, Price JE, Esumi N, Tsan R, Petty CM, Bucana CD and Bar-Eli M (1994) Terminal differentiation and apoptosis in experimental lung metastasis of human osteogenic sarcoma cells by wild type p53. Oncogene 9: 1877-1883

Ramqvist T, Magnusson KP, Wang Y, Szelely L, Klein G and Wiman KG (1993) Wildtype p53 induces apoptosis in a Burkitt lymphoma (BL) line that carries mutant p53. Oncogene 8: 1495-1500

Selvakumaran M, Lin H-K, Miyashita T, Wang HG, Krajewski S, Reed JC, Hoffman B and Libermann D (1994) Immediate early up-regulation of bax expression by p53 but not TGF beta 1: a paradigm for distinct apoptotic pathways. Oncogene 9: $1791-1798$
Sentman C, Shutter J, Hockenbery D, Kanagawa O and Korsemeyer SJ (1991) bcl-2 inhibits multiple forms of apoptosis but not negative selection in thymocytes. Cell 67: $879-888$

Shaw P, Bovey R, Tardy S, Sahli R, Sordat B and Costa J (1992) Induction of apoptosis by wild-type 553 in a human colon tumor-derived cell line. Proc. Natl. Acad. Sci. USA 89: 4495-4499

Stalder T, Hahn S and Erb P (1994) Fas antigen is the major target molecule for CD4+T cell-mediated cytotoxicity. J. Immunol. 152: 1127-1133

Strasser A, Harris AW and Cory S (1991) bcl-2 transgene inhibits T cell death and perturbs thymic self-censorship. Cell 67: 889-899

Suda T, Takahashi T, Goldstein P and Nagata S (1993) Molecular cloning and expression of the Fas ligand, a novel member of the tumor necrosis factor family. Cell 75: $1169-1178$

Th'ng KH, Garewal G, Kearney L, Rassool F, Melo JV, White H, Catovsky D, Foroni L, Luzzatto L and Goldman JM (1987) Establishment and characterization of three new malignant lymphoid cell lines. Int. J. Cancer 3989-3993

Trauth BC, Klas C, Peters AM, Matzku S, Moller P, Falk W, Debatin K-Mand Krammer PH (1989) Monoclonal antibody-mediated tumor regression by induction of apoptosis. Science 245: 301-305

Ulrich MJ and Ley TJ (1990) Function of normal and mutated gamma-globin gene promoters in electroporated K562 erythroleukemia cells. Blood 75: 990-999

Wang X, Pai J-T, Wiedenfeld EA, Medina JC, Slaughter CA, Goldstein JL and Brown MS (1995) Purification of an interleukin-1 beta converting enzyme-related cysteine protease that cleaves sterol regulatory element-binding proteins between the leucine zipper and transmembrane domains. J. Biol. Chem. 270: $18044-18050$

Wang X, Zelenski NG, Yang J, Sakai J, Brown MS and Goldstein JL (1996) Cleavage of sterol regulatory element binding proteins (SREBPs) by CPP32 during apoptosis. EMBO J. 15: 1012-1020

Wolf $D$ and Rotter V (1985) Major deletions in the gene encoding the p53 tumor antigen cause lack of $p 53$ expression in HL-60 cells. Proc. Natl. Acad. Sci. USA 82790-82794

Yang E and Korsmeyer SJ (1996) Molecular thanatopsis: a discourse on the BCL2 family and cell death. Blood 88: 386-401

Yonish-Rouach E, Resnitzky D, Lotem S, Sachs L, Kimchi A and Oren M (1991) Wildtype p53 induces apoptosis of myeloid leukemic cells that is inhibited by interleukin-6. Nature 352: 345-347

Zhan Q-M, Fan S-J, Bae I, GuilloufC, Lieberman DA, O'Connor PMand Fornace AJJ (1994) Induction of bax by genotoxic stress in human cells correlates with norma p53 status and apoptosis. Oncogene 9: 3743-3751

Zhang W, Funk WD, Wright WE, Shay JW and Deisseroth AB (1993) Novel DNA binding of p53 mutants and their role in transcriptional activation. Oncogene 8 : $2555-2559$

Zhang W, Guo X-Y, Hu G-Y, Liu W-B, Shay JW and Deisseroth AB (1994a) A temperature-sensitive mutant of human p53. EMBO J. 13: 2535-2544

Zhang W, Hu G and Deisseroth A (1992) Polymorphismatcodon 72 of thep53 gene in human acute myelogenous leukemia. Gene 117: 271-275

Zhang W, McClain CD, Gau J-P, Guo X-Y and Deisseroth AB (1994b), Hyperphosphorylation of p53 induced by okadaic acid attenuates its transcriptional activation function. Cancer Res. 54: 4448-4453

Zhang W, Randhawa GS, Gau J-P, Shay JW and Deisseroth AB (1995) The firstintron of human $\mathrm{H}$-ras is regulated by $\mathrm{p} 53$ : Mediation of specific activation by a p53binding element. Int. J. Oncol. 7: 1021-1028 